\title{
Bioethanol production of second generation from corn cob
}

\section{Producción de bioetanol de segunda generación a partir de olote de maíz}

\author{
SANDOVAL-SALAS, Fabiola $\dagger^{1 *}$, MÉNDEZ-CARRETO, Carlos $^{1}$, BARRALES-FERNÁNDEZ, \\ Christell ${ }^{1}$ and ORTEGA-AVILA, Graciela ${ }^{1}$
}

Tecnológico Nacional de México/ITS Perote, Laboratorio de Investigación

ID $1^{\text {st }}$ Author: Fabiola, Sandoval-Salas / ORC ID: 0000-0001-9267-4974, CVU CONACYT ID: 71814, SNI I

ID $1^{\text {st }}$ Co-author: Carlos, Méndez-Carreto / ORC ID: 0000-0002-2897-4453, CVU CONACYT ID: 227409

ID $2^{\text {nd }}$ Co-author: Christell, Barrales-Fernández / ORC ID: 0000-0002-9909-7572, CVU CONACYT ID: 697471

ID $3^{\text {rd }}$ Co-author: Graciela, Ortega-Avila / ORC ID: 0000-0002-9395-246X, CVU CONACYT ID: 1019267

\begin{abstract}
Bioethanol production from lignocellulosic materials has several environmental and economic advantages. In this work, corn cob was used to produce ethanol by fermentation. The cob was grounded, hydrolyzed chemically, and then enzymatically. Later, hydrolysates were used as a carbon source to formulate culture media that were inoculated with Saccharomyces cerevisiae; hollocellulose content was quantified by the ASTM D-1104 method; cellulose content by the TAPPTI 212 method; lignin content by the NREL / TP-510-42618 method; and ethanol was quantified by HPLC. In fermentation, bioethanol yields of up to $3.5 \mathrm{~g} / \mathrm{L}$ were found, equivalent to $\mathrm{Y}_{\mathrm{P} / \mathrm{S}}$ value of 0.46 , representing approximately $90 \%$ of the theoretical yield.
\end{abstract}

$\begin{array}{llll}\begin{array}{l}\text { Pretreatment, Enzymatic hydrolysis, } \\ \text { Lignocellulose }\end{array} & \begin{array}{l}\text { Pretratamiento, Hidrólisis enzimática, } \\ \text { Lignocelulosa }\end{array}\end{array}$

\begin{abstract}
Resumen
La producción de bioetanol a partir de materiales lignocelulósicos presenta varias ventajas ambientales y económicas. En este trabajo se utilizó olote de maíz para producir etanol por vía fermentativa. El olote se molió y se hidrolizó por vía química seguida de hidrólisis enzimática. Posteriormente, los hidrolizados se utilizaron como fuente de carbono para formular medios de cultivo que se inocularon con Saccharomyces cerevisiae; el contenido de holocelulosa se cuantificó mediante el método ASTM D-1104, la celulosa por el método TAPPTI 212 y la lignina por el método de NREL/TP-510-42618; el etanol se cuantificó por HPLC. En la fermentación se encontraron rendimientos de bioetanol de hasta $3.5 \mathrm{~g} / \mathrm{L}$, lo que equivale a un valor de $\mathrm{Y}_{\mathrm{P} / \mathrm{S}}$ de 0.46 , lo que representa alrededor del $90 \%$ del rendimiento teórico.
\end{abstract}

Citation: SANDOVAL-SALAS, Fabiola, MÉNDEZ-CARRETO, Carlos, BARRALES-FERNÁNDEZ, Christell and ORTEGA-AVILA, Graciela. Bioethanol production of second generation from corn cob. Journal Renewable Energy. 2021. 5-15: $29-33$

\footnotetext{
* Author Correspondence (e-mail: investiga.itspe @gmail.com)

$\dagger$ Researcher contributing as first author.
} 


\section{Introduction}

In the face of the potential crisis due to the gradual depletion of oil reserves, biofuels are considered a potential alternative for use in transportation systems due to several advantages, among which are their net balance close to zero in $\mathrm{CO}_{2}$ emissions, their flexibility to mix with fossil fuels in different ratios, their renewable nature, and the fact their production causes significantly less environmental problems locally (Gnansounou, 2001; Saini et al., 2015; Cunha et al., 2019).

Bioethanol is a sustainable, renewable liquid fuel used to replace petroleum-derived gasolines (Saini et al., 2015; Aditiya et al., 2016; Cunha et al., 2019; Mensah et al., 2021; Noppawan et al., 2021). This biofuel may be produced by fermentation from different raw materials. Bioethanol is classified according to the type of substrate used; thus, it may be produced from sugars, flours, and lignocellulosic materials (Saini et al., 2015; Dong et al., 2021; Patel y Shah, 2021). Bioethanol produced from lignocellulosic materials (agro-industrial waste, woods and high biomass fodder grasses), also known as second generation bioethanol, is considered an alternative with a better outlook than its first generation counterpart (Kelbert et al., 2015; Barros-Rios et al., 2016; Soares et al., 2017; Patel and Shah, 2021); it is produced from raw materials such as sugarcane, maize, wheat, barley, sorghum, potato and other agricultural waste (Monteiro, 2010; Saini et al., 2015; Soares et al., 2017; Munu et al., 2021; Noppawan et al., 2021).

In order to develop bioethanol production processes from lignocellulosic materials it is required to consider the application of a pretreatment before hydrolysis, allowing the reduction of materials in physical size, provoking cellulose and hemicellulose and guaranteeing that enzymes have better access to hydrolyze carbohydrates into fermentable sugars (Kelbert et al., 2015; Aditiya et al., 2016; Cunha et al., 2019; Noppawan et al., 2021; Patel and Shah, 2021).

Corn waste, including stubble and cobs, represents a good alternative for second generation bioethanol production: corn crops are abundant and widely distributed geographically, and it is feasible to grow food and produce energy simultaneously.
It has the additional advantage of reducing greenhouse gas emissions, without the need of making changes in soil usage for energy production purposes (Kelbert et al., 2015; Saini et al., 2015; Dong et al., 2021; Noppawan et al., 2021).

Corn cob is considered a byproduct of corn production, with high possibilities for use, given that for each ton of corn produced, around $170 \mathrm{~kg}$ of corn cob are produced. Since this material contains high amounts of cellulose and hemicellulose, it is possible to use it for fermentation production of bioethanol, xylitol, and other organic compounds (Cordoba et al., 2013; Mensah et al., 2021).

This work describes the chemical characterization of the principal components of corn cob produced in the Cofre y Valle de Perote region, as well as the evaluation of the enzymatic hydrolysis process (with and without treatment), and finally, the use of hydrolysates for bioethanol fermentation.

\section{Materials and methods}

\subsection{Raw material obtention}

Corn cob was collected from the 2017 harvest in the Valle y Cofre de Perote region. Corn cobs were crushed in a hammer mill (Azteca). The material was then stored in $20 \mathrm{Kg}$ sacks and passed through a 500-micron sieve (Montinoz). Finally, the material was dried at $60^{\circ} \mathrm{C}$ at a constant weight and stored in $5.1 \mathrm{~L}$ plastic containers until use.

\subsection{Determination of biomass components}

For the determination of extractable compounds $15 \mathrm{~g}$ simples were used; they were refluxed in acetone for $5 \mathrm{~h}$ and triple rinsed with distilled water. Extractables content was determined by the weight difference before and after extraction. Holocellulose content was quantified by the ASTM D-1104 method; cellulose content was quantified by the TAPPTI 212 method; and lignin was quantified by the NREL/TP-51042618 method.

\subsection{Hydrolysis pretreatment of corn cob flour}

Corn cob samples were subjected to three different pretreatments in autoclave at $121^{\circ} \mathrm{C}$ for $40 \mathrm{~min}$ 
In the first pretreatment, an alkaline solution $(\mathrm{NaOH}$ al $8 \%)$ was used; in the second pretreatment, an acidic solution $\left(\mathrm{H}_{2} \mathrm{SO}_{4}\right.$ al $\left.2 \%\right)$ was used; in the third pretreatment, only distilled water was used. A 1:20 bagasse:solution (W/V) ratio was used in all pretreatments. After pretreatment, simples were filtered, bagasse was triple rinsed with distilled water and dried in a stove at $60^{\circ} \mathrm{C}$ for $24 \mathrm{~h}$; the liquid fraction was neutralized with $\mathrm{HCl}(0.1 \mathrm{~N})$ or $\mathrm{NaOH}(0.1 \mathrm{~N})$, and sugar concentration was determined by the DNS method (Miller, 1959).

For enzymatic hydrolysis, the pre-treated bagasse simples were suspended in a sodium acetate buffer with $\mathrm{pH} 4.8(50 \mathrm{mM})$, at a 1:8 bagasse and acetate buffer ratio (W/V). Hydrolysis was conducted using a commercial cellulase complex (Cellulase 10XL, Enziquim), at $1 \%$ ratio at $55^{\circ} \mathrm{C}$ for $3 \mathrm{~h}$.

\subsection{Fermentation}

Hydrolysates obtained were supplemented with $0.3 \%$ ammonium phosphate and inoculated with a Saccharomyces cerevisiae culture $\left(1 \times 10^{5}\right.$ $\mathrm{cel} / \mathrm{mL}$ ) in $\log$ phase, in $250 \mathrm{~mL}$ beakers. Cultures were incubated at $25^{\circ} \mathrm{C}$ in a rotary shaker $(120 \mathrm{rpm})$ for $48 \mathrm{~h}$. During fermentation, sugar consumption was followed through quantification of residual glucose in the medium using the GOD-GOP method (Trinder) and determination of ethanol concentration by HPLC, under the conditions listed in Table 1.

\begin{tabular}{|l|l|}
\hline Parameter & Condition \\
\hline Method & Isocratic \\
\hline Column & Shodex SH 1011 \\
\hline Mobile phase & $\mathrm{H}_{2} \mathrm{SO}_{4}, 5 \mathrm{mM}$ \\
\hline Injected sample & $20 \mu \mathrm{L}$ \\
\hline Detector & Refractive index \\
\hline Flow rate & $0.6 \mathrm{~mL} / \mathrm{min}$ \\
\hline
\end{tabular}

Table 1 Conditions under which glucose identification and quantification by HPLC was conducted Source: The Authors

\section{Results and discussion}

After crushing the corn cobs a fine off-white flour was obtained, with a pleasant aroma, easily suspended in water (Figure 1).

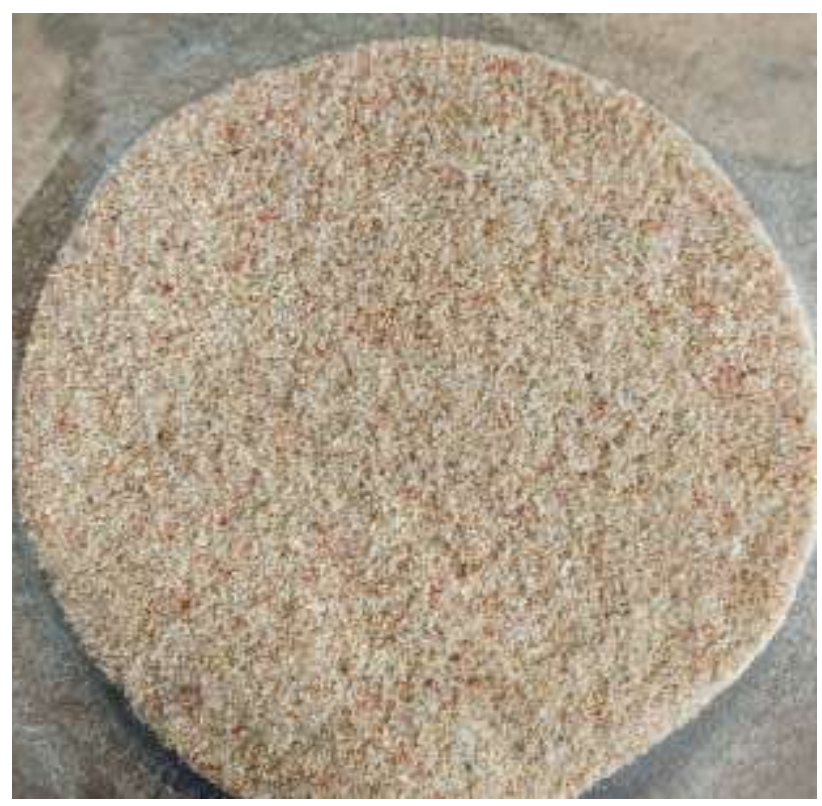

Figure 1 Appearance of corn cob flour used for bioethanol production

Source: The Authors

According to Zabel et al. (2017) and Martínez (2015), corn cob has a high cellulose concentration, ranging between $42-45 \%$. The results obtained in the characterization of this component showed values slightly lower than previously reported; hemicellulose was found within the range reported in prior studies (35 to $39 \%$ ) and lignin was slightly higher than expected (14-15\%; Table 2).

\begin{tabular}{|l|r|}
\hline Component & Content in bagasse g/g \\
\hline Cellulose & $382 \pm 12$ \\
\hline Hemicellulose & $378 \pm 18$ \\
\hline Hollocellulose & $761 \pm 53$ \\
\hline Lignin & $223 \pm 17$ \\
\hline Extractables & $129 \pm 07$ \\
\hline
\end{tabular}

Table 2 Corn cob components Source: The Authors

Even though sugar concentrations obtained in the chemical pretreatment with diluted acid were higher with diluted sugars (Table 3), it was observed that the final yield after enzymatic hydrolysis is higher when alkaline solutions are used, under the same process conditions. In general, it is recognized that diluted acid solutions hydrolyze mainly hemicellulose and partially cellulose (Saini et al., 2015; Aditiya et al., 2016; Dong et al., 2021); thus, it is possible this is the reason why yields are higher with this treatment. Under these conditions, it was not possible to hydrolyze more carbohydrates during enzymatic hydrolysis, indicating lignin removal is absent, therefore access of cellulose enzymes to the substrate is limited.

SANDOVAL-SALAS, Fabiola, MÉNDEZ-CARRETO, Carlos, BARRALES-FERNÁNDEZ, Christell and ORTEGA-AVILA, Graciela Bioethanol production of second generation from corn cob. Journal Renewable Energy. 2021 
On the other hand, alkaline solutions remove lignin and hemicellulose and increase exposed surface area (Aditiya et al., 2016; Dong et al., 2021). This characteristic allowed hydrolyzation of a higher amount of cellulose after enzymatic treatment. The maximum yield of reducing sugars was $19.81 \%$ when using alkaline pretreatment and enzymatic hydrolysis with cellulase enzymes.

\begin{tabular}{|c|c|c|c|c|}
\hline \multirow[t]{2}{*}{ Pretreatment } & \multicolumn{2}{|c|}{ Corn cob yield mg AR/g } & \multicolumn{2}{|l|}{ Total yield } \\
\hline & $\begin{array}{c}\text { After } \\
\text { pretreatment* }\end{array}$ & $\begin{array}{c}\text { After } \\
\text { enzymatic } \\
\text { hydrolysis* }\end{array}$ & $\begin{array}{c}\text { Corn } \\
\text { cob mg } \\
\text { AR/g }\end{array}$ & $\%$ \\
\hline Diluted acid & $\begin{array}{r}173.65 \pm \\
22.45 \\
\end{array}$ & 0 & 173.65 & 17.36 \\
\hline Alkaline & $57.55 \pm 6.93$ & $\begin{array}{r}151.24 \pm \\
17.93 \\
\end{array}$ & 196.13 & 19.81 \\
\hline $\begin{array}{l}\text { No } \\
\text { pretreatment }\end{array}$ & 0 & $\begin{array}{r}55.91 \pm \\
2.22\end{array}$ & 55.91 & 5.59 \\
\hline
\end{tabular}

Table 3 Corn cob components (* Average of 5 repetitions) Source: elaborated by the authors

Bioethanol yields with corn cob hydrolysates fermentation was up to $3.5 \mathrm{~g} / \mathrm{L}$ (Figure 2), which is equivalent to a $0.46 \mathrm{Y}_{\mathrm{P} / \mathrm{S}}$ value, representing around $90 \%$ of the theoretical yield. These results match those reported by Sánchez y Cardona (2005) regarding ethanol production by fermentation.

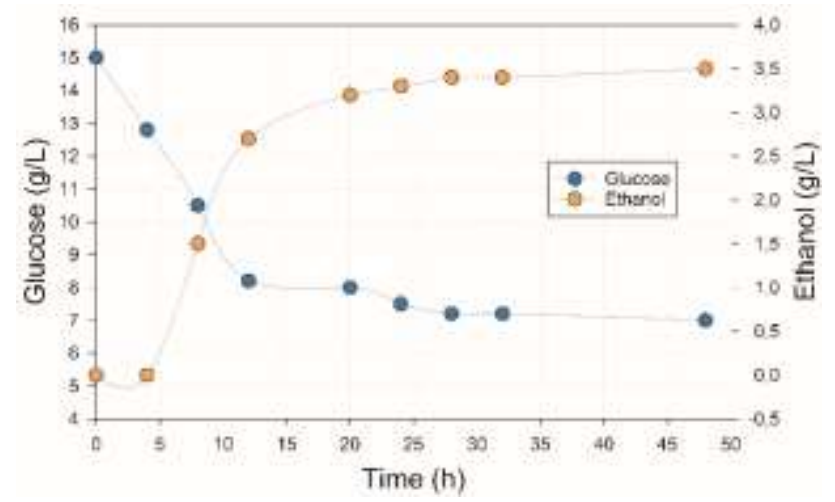

Figure 2 Sugar consumption and bioethanol production from corn cob hydrolysates

Source: The Authors

Dong et al., (2021) reported on corn husk fermentation, for which they hydrolyzed the material with acid and enzymes prior to fermentation, and obtained butanol yields of 9.5 $\mathrm{g} / \mathrm{L}$, with $35.7 \mathrm{~g} / \mathrm{L}$ initial concentration. However, in this case, they were able to hydrolyze a higher amount of hemicellulose, leaving a higher amount of fermentable sugars.

Mensah et al., (2021) associated low ethanol production to inhibitors developed after hydrolysis, in their study they obtained 0.045 $\mathrm{L} / \mathrm{kg}$ of ethanol, using corn husks as substrate.

\section{Conclusions}

Corn cob lignocellulosic biomass yielded values close to $40 \%$, allowing to obtain up to $19.81 \%$ of fermentable sugars, using an alkaline biomass pretreatment and later through enzymatic hydrolysis with a cellulose. These hydrolysates proved to be appropriate for bioethanol production and reached yields in fermentation close to the theoretical maximum $(90 \%)$.

\section{References}

Aditiya H.B., Mahlia T.M.I., Chong W.T. Nur H., Sebayang A.H. (2016). Renewable and sustainable Energy reviews 66:631-656.

Barros Ríos J., Romani A., Peleteiro S., Garrote G. Ordas B. (2016). Second-generation bioethanol of hydrothermally pretreated stover biomass from maize genotypes. Biomass and Bioenergy 90:42-49.

Córdoba J.A., Salcedo E., Rodríguez R., Zamora J.F.,Manríquez R., Contreras H., Robledo J., Delgado E. (2013). Caracterización y valoración química del olote: degradación hidrotérmica bajo condiciones subcríticas. Revista Latinoaméricana de Química 41:175-184.

Cunha, J. T., Soares, P. O., Romaní, A., Thevelein, J. M., Domingues, L. (2019). Xylose fermentation efficiency of industrial Saccharomyces cerevisiae yeast with separate or combined xylose reductase/xylitol dehydrogenase and xylose isomerase pathways. Biotechnology for biofuels, 12(1), 1-14.

Dong, J. J., Ma, B. J., Liu, Y. M., Li, H., Gong, L., Han, R. Z., Xu, G. C., Ni, Y. (2021). Coproduction of xylose and biobutanol from corn stover via recycling of sulfuric acid pretreatment solution. Systems Microbiology and Biomanufacturing, 1(2), 200-207.

Gnansounou E. (2011). Assessing the sustainability of biofuels: A logic-based model. Energy 36:2089-2096.

Kelbert M., Romani A. Coelho E. Pereira F.B. Teixeira J.A. Dominges L. (2015). Lignocellulosic bioethanol production with revalorization of low-cost agroindustrial byproducts as nutritional supplements. Industrial Crops and Products 64:16-24. 
Martínez. (2015). Análisis Tecno-Económico de la producción de bioetanol a partir de olote de maíz. Tesis de Maestría en Ingeniería Química. Universidad Iberoamericana. México D.F. 81 p.

Mensah, M. B., Jumpah, H., Boadi, N. O., Awudza, J. A. (2021). Assessment of quantities and composition of corn stover in Ghana and their conversion into bioethanol. Scientific African, 12, e00731.

Miller, G.L. (1959). Use of dinitrosalicylic acid reagent for determination of reducing sugar. Anal. Chem. 31: 426-428.

Monteiro. M. (2010). Situación de los biocombustibles de 2da y 3era generación en América Latina y Caribe. Organización Latinoamericana de Energía. Instituto Interamericano de Cooperación para la Agricultura (IICA).

Munu, N., Banadda, N., Kiggundu, N., Zziwa, A., Kabenge, I., Seay, J., Kambugu, R., Wanyama, J., Schmidt, A. (2021). Transforming corn stover to useful transport fuel blends in resource-limited settings. Energy Reports, 7, 1256-1266.

Noppawan, P., Lanctôt, A. G., Magro, M., Navarro, P. G., Supanchaiyamat, N., Attard, T. M., \& Hunt, A. J. (2021). High pressure systems as sustainable extraction and pre-treatment technologies for a holistic corn stover biorefinery. BMC chemistry, 15(1), 1-11.

Patel, A., Shah, A. (2021). Integrated lignocellulosic biorefinery: Gateway for production of second generation ethanol and value added products. Journal of Bioresources and Bioproducts.

Saini, J. K., Saini, R., Tewari, L. (2015). Lignocellulosic agriculture wastes as biomass feedstocks for second-generation bioethanol production: concepts and recent developments. 3 Biotech, 5(4), 337-353.

Sánchez O.J. y Cardona C.A. (2005). Producción biotecnológica de alcohol carburante. I. Obtención a partir de diferentes materias primas. Interciencia 30(11):671-678.

Soares, J., Demeke, M. M., Van de Velde, M., Foulquié-Moreno, M. R., Kerstens, D., Sels, B. F., Verplaeste, A., Fernandes, P. M. B. (2017).
Fed-batch production of green coconut hydrolysates for high-gravity second-generation bioethanol fermentation with cellulosic yeast. Bioresource technology, 244, 234-242.

Zabed H. Sahu J.N. Suely A. Boyce A.N. Faruq G. (2017). Bioethanol production from renewable sources: Current perspectives and technological progress. Renewable and Sustainable Energy Reviews 71:475-501. 